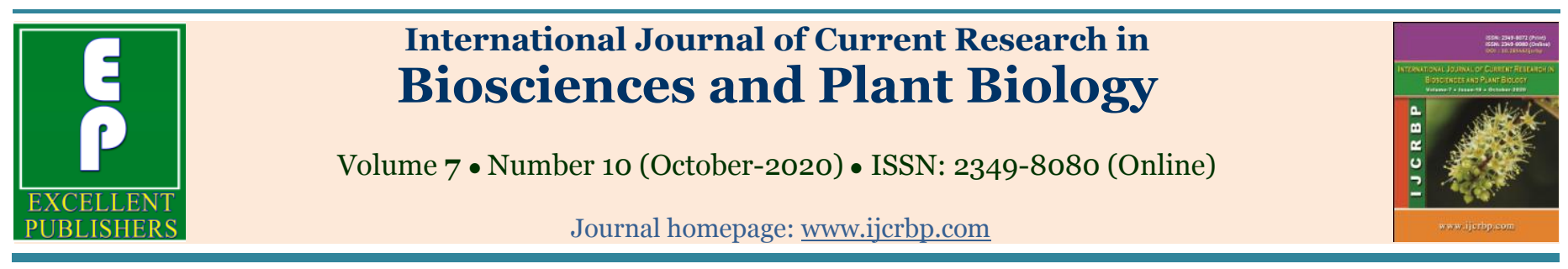

\title{
Effect of reduced nitrogen fertilizer rate on nitrogen uptake and yield of spinach (Amaranthus spp.)
}

\author{
Faridah Manaf $^{*}$, Roslan Ismail ${ }^{2}$ and Arina Shairah Abdul Sukor ${ }^{2}$ \\ ${ }^{1}$ Malaysian Agricultural Research and Development Institute (MARDI), 4340o Serdang, Selangor, Malaysia \\ ${ }^{2}$ Faculty of Agriculture, University Putra Malaysia, 43400 Serdang, Selangor, Malaysia \\ *Corresponding author; e-mail: faridah@mardi.gov.my
}

\begin{tabular}{|c|c|}
\hline Article Info & ABSTRACT \\
\hline $\begin{array}{l}\text { Date of Acceptance: } \\
18 \text { September } 2020\end{array}$ & \multirow{3}{*}{$\begin{array}{l}\text { Reducing nitrogen (N) fertilizer rate have beneficial effect on } \mathrm{N} \text { uptake by plants. } \\
\text { Studies on reducing } \mathrm{N} \text { rate in sweet potato and beetroot to improve their growth and } \\
\text { yield are well documented but the effect of decreased } \mathrm{N} \text { rate on } \mathrm{N} \text { uptake by leafy } \\
\text { vegetables are limited. A glasshouse experiment was conducted to determine the effect } \\
\text { of different } \mathrm{N} \text { rate on } \mathrm{N} \text { uptake of green spinach. Treatments evaluated were (i) soil } \\
\text { alone, and (ii) different } \mathrm{N} \text { fertilizer rate }(12,24,36,60,90 \text { and } 120 \mathrm{~kg} \mathrm{~N} / \mathrm{ha} \text { ). } \\
\text { Treatments were applied at } 14 \text { days after seeding (DAS) at a uniform rate of } 2 \mathrm{t} / \mathrm{ha} \text {. } \\
\text { Results revealed that moderate } \mathrm{N} \text { input between } 12 \text { to } 36 \mathrm{~kg} \mathrm{~N} / \mathrm{ha} \text { improved } \mathrm{N} \text { uptake } \\
\text { and yield of spinach compared with lower rate of } \mathrm{N} \text { input (o to } 12 \mathrm{~kg} \mathrm{~N} / \mathrm{ha} \text { ) but higher } \mathrm{N} \\
\text { level of } 90 \mathrm{~kg} \mathrm{~N} / \mathrm{ha} \text { was most effective in improving } \mathrm{N} \text { uptake and fresh yield. The } \\
\text { effectiveness of } \mathrm{N} \text { input at } 90 \mathrm{~kg} \mathrm{~N} / \mathrm{ha} \text { corresponded to the optimum retention of soil } \mathrm{N} \\
\text { resulting in timely availability of } \mathrm{N} \text { for uptake by spinach leading to higher yield. } \\
\text { Although treatment with excess } \mathrm{N} \text { (120 kg } \mathrm{N} / \mathrm{ha} \text { ) improved } \mathrm{N} \text { uptake, the decline in } \\
\text { yield was because of soil nutrient imbalance that inhibited other nutrients required by } \\
\text { plants for growth and development. The findings from the study suggest that reducing } \\
\mathrm{N} \text { fertilizer rate improves } \mathrm{N} \text { uptake in leafy vegetables without reducing productivity } \\
\text { depending on their specific } \mathrm{N} \text { requirement. }\end{array}$} \\
\hline Keywords & \\
\hline $\begin{array}{l}\text { Fertilizer } \\
\text { Leafy vegetable } \\
\text { Nitrogen } \\
\text { Nutrient management } \\
\text { Soil fertility }\end{array}$ & \\
\hline
\end{tabular}

\section{Introduction}

Managing soil fertility particularly nitrogen $(\mathrm{N})$ is crucial in both organic and conventional agriculture system. Nitrogen exists in the soil in many forms. Readily available $\mathrm{N}$ and other $\mathrm{N}$ sources added into the soil are subjected to biogeochemical transformations into inorganic form called mineralization. Ammonium and nitrate are the common forms of inorganic nitrogen for plant use. Inorganic $\mathrm{N}$ for plant use is an essential nutrient required for plant growth and development. It is vital due to its role as a component of chlorophyll, the compound by which plants use sunlight energy to produce sugars from water and carbon dioxide through the process of photosynthesis.

Added $\mathrm{N}$ is subjected to losses mostly through leaching and nutrient removal during crop harvesting. However, optimal use of $\mathrm{N}$ application to crops neither resulted in the loss of organic matter nor adversely affected microbial activity in the soil (Singh, 2018). Nevertheless, improper and excessive $\mathrm{N}$ fertilization could lead to eutrophication particularly nitrate pollution in 
ground or surface water (Khan et al., 2018) besides causing an imbalance of soil $\mathrm{C}: \mathrm{N}$ ratio resulting in low soil carbon content (Junyong et al., 2018; Muhammad et al., 2019).

Spinach (Amaranthus spp.) is a type of leafy green vegetable commonly cultivated around the globe as an important raw material in the food industry. Spinach can take up $\mathrm{N}$ efficiently besides containing phytonutrients such as flavonoid and phenolic (Ida et al., 2020; Machado et al., 2018). Also, spinach is a popular vegetable that is frequently bought and consumed among diverse community in Malaysia. Based on statistical sources released by the Malaysian Department of Agriculture (DOA), the total spinach production until 2018 is 75,220 metric tonnes (mt). That amount had contributed $46 \%$ to the total vegetable production in Malaysia in 2018 worth USD 283,000 (DOA, 2018). Contribution of the vegetable industry to the livelihood of farmers and the country's economy suggest a need to determine the optimal use of $\mathrm{N}$ fertilizer without incurring additional production cost but simultaneously improving vegetable productivity.

At present, the mechanism by which $\mathrm{N}$ input rate affect $\mathrm{N}$ uptake in leafy vegetables is still poorly understood. As reported by Darren et al. (2020) and Laila et al. (2019), excessive dose of $\mathrm{N}$ inhibited root growth and development, thus reducing the ability of roots to absorb nutrients and water efficiently. These findings were agreed by Mohamed et al (2020), their study also showed that excessive dose of $\mathrm{N}$ (above $500 \mathrm{~kg} \mathrm{~N} / \mathrm{ha}$ ) lead to $\mathrm{N}$ losses and had no significant effects on tuber yield.

Based on the preceding rationale, the objective of this study was to determine the effect of different $\mathrm{N}$ fertilizer rate on $\mathrm{N}$ uptake of green spinach. In this study we hypothesized that by giving $\mathrm{N}$ at lower and higher input will result in different amount of plant uptake and yield. This hypothesis is based on the assumption that $\mathrm{N}$ plays a significant role as primary macronutrient for plant growth and development. To test this hypothesis, a glasshouse experiment was conducted to determine $\mathrm{N}$ uptake and yield of spinach. Information obtained from this study could provide insights on $\mathrm{N}$ fertilizer and nutrient management for commercial vegetable production.

\section{Materials and methods}

\section{Experimental site description, planting and maintenance}

A glasshouse experiment was conducted for two cycles at the Serdang research station located within the vicinity of the Malaysia Agricultural Research and Development Institute (MARDI), Selangor, Malaysia. The test crop used was rounded leaf green spinach (Amaranthus spp.). In this study, the potting media used was of sandyclay type soil. Green spinach was planted by direct seeding in pots containing $10 \mathrm{~kg}$ potting media. Spinach seedlings were thinned to ten seedlings/pot at seven days after seeding. Fertilization, watering and weeding were managed using standard agronomic practices.

\section{Experimental design and treatments}

The experimental design was randomized complete block design with five replications. The treatments evaluated are summarized in Table 1. Treatments were applied after fourteen days after seeding (DAS) with a rate of $13.5 \mathrm{~g} /$ pot.

Table 1. Treatments evaluated and their fertilizer application rate in a glasshouse experiment to determine their effect on $\mathrm{N}$ uptake and yield of spinach.

\begin{tabular}{ll}
\hline Treatments & Fertilizer application rate (kg N/ha) \\
\hline T1 & o (Control) \\
T2 & 12 \\
T3 & 24 \\
T4 & 36 \\
T5 & 60 \\
T6 & 90 \\
T7 & 120 \\
\hline
\end{tabular}

\section{Soil analysis}

Soil samples were taken at depth of o to $20 \mathrm{~cm}$ before planting (o Day), after treatment application (20 DAS) and at harvest (35 DAS) to determine soil chemical ( $\mathrm{N}$, carbon (C) and $\mathrm{pH}$ ) changes to treatments throughout the growth phases of the spinach. Soil samples were air-dried and ground to pass a $2 \mathrm{~mm}$ sieve. Soil total $\mathrm{N}$ and $\mathrm{C}$ were determined using a CHNOS analyser (ELEMENTAR Vario Macro Modules 11.44-5201). 
For this analysis, $60 \mathrm{mg}$ of air-dried soil samples were used. Soil $\mathrm{pH}$ was measured based on a ratio of 1:2.5 soil to water suspension using a $\mathrm{pH}$ meter (Mettler Toledo, Delto 320).

\section{Nitrogen uptake and spinach fresh yield}

Fresh spinach harvest was carried out at 35 DAS, and spinach fresh weight was measured using a digital balance (SQW-3, SmartWEIGHT Malaysia) and expressed in gram as crop yield. Whole plant parts of the harvested spinach were oven dried at $60^{\circ} \mathrm{C}$, ground and analysed for total $\mathrm{N}$ using the CHNOS analyser (ELEMENTAR Vario Macro Modules 11.44-5201). N uptake was determined by multiplying the contents of nitrogen in spinach with their dry weight.

\section{Statistical analysis}

Analysis of variance (ANOVA) was used to test significant theeffect of treatments whereas means of treatments were compared using Tukey's HSD test at $\mathrm{P} \leq 0.05$. Statistical Analysis
System (SAS) Version 9.4 was used for the statistical analysis.

\section{Results and discussion}

\section{Effect of different $\mathrm{N}$ input rate on soil $\mathrm{pH}$ and total $\mathbf{N}$}

Results on the changes in soil chemical properties subjected to different $\mathrm{N}$ fertilization rate throughout the growth phases of spinach is presented in Table 2. At 20 DAS, soil pH was generally similar irrespective of treatments. However, $\mathrm{T} 1$ and $\mathrm{T} 4$ showed significantly higher soil pH compared with T6. Also, both T1 and T4 showed low decrement in soil $\mathrm{pH}$ compared to other treatments throughout the growth phases of spinach. The small changes in soil $\mathrm{pH}$ suggested that $\mathrm{N}$ fertilizer applied under $\mathrm{T} 1$ and T4 were fully taken up by spinach for its growth and development. This observation is consistent with the higher content of $\mathrm{N}$ in spinach under $\mathrm{T} 4$ (Table 3). Moreover, the total utilization of $\mathrm{N}$ by crop prevents $\mathrm{N}$ loss through leaching.

Table 2. Effects of different $\mathrm{N}$ fertilizer rate on soil $\mathrm{pH}$ and total nitrogen and soil organic carbon (SOC) after two cycles of spinach cultivation.

\begin{tabular}{lllll}
\hline Planting stage & Treatment & pH & Total N (\%) & SOC (\%) \\
\hline Before planting (o DAS) & Soil initial & $6.51 \pm 0.02$ & $0.19 \pm 0.01$ & $1.58 \pm 0.02$ \\
\hline Middle of cropping (20 DAS) & T1 & $6.47 \pm 0.25 \mathrm{a}$ & $0.48 \pm 0.03 \mathrm{~b}$ & $5.48 \pm 0.24 \mathrm{a}$ \\
& $\mathrm{T} 2$ & $6.31 \pm 0.19 \mathrm{ab}$ & $0.53 \pm 0.02 \mathrm{ab}$ & $6.04 \pm 0.34 \mathrm{a}$ \\
& $\mathrm{T} 3$ & $6.13 \pm 0.12 \mathrm{ab}$ & $0.82 \pm 0.12 \mathrm{a}$ & $6.71 \pm 0.61 \mathrm{a}$ \\
& $\mathrm{T} 4$ & $6.36 \pm 0.07 \mathrm{a}$ & $0.67 \pm 0.08 \mathrm{ab}$ & $5.34 \pm 0.43 \mathrm{a}$ \\
& $\mathrm{T} 5$ & $6.13 \pm 0.21 \mathrm{ab}$ & $0.60 \pm 0.08 \mathrm{ab}$ & $6.60 \pm 0.85 \mathrm{a}$ \\
& $\mathrm{T} 6$ & $5.63 \pm 0.15 \mathrm{~b}$ & $0.65 \pm 0.06 \mathrm{ab}$ & $5.70 \pm 0.35 \mathrm{a}$ \\
& $\mathrm{T} 7$ & $6.27 \pm 0.08 \mathrm{ab}$ & $0.54 \pm 0.05 \mathrm{ab}$ & $5.19 \pm 0.19 \mathrm{a}$ \\
\hline At harvesting (35 DAS) & $\mathrm{T} 1$ & $6.02 \pm 0.24 \mathrm{a}$ & $0.34 \pm 0.02 \mathrm{a}$ & $4.18 \pm 0.28 \mathrm{a}$ \\
& $\mathrm{T} 2$ & $6.18 \pm 0.19 \mathrm{a}$ & $0.37 \pm 0.04 \mathrm{a}$ & $3.43 \pm 0.25 \mathrm{a}$ \\
& $\mathrm{T} 3$ & $5.42 \pm 0.18 \mathrm{a}$ & $0.35 \pm 0.05 \mathrm{a}$ & $4.20 \pm 0.61 \mathrm{a}$ \\
& $\mathrm{T} 4$ & $5.41 \pm 0.12 \mathrm{a}$ & $0.44 \pm 0.02 \mathrm{a}$ & $3.70 \pm 0.48 \mathrm{a}$ \\
& $\mathrm{T} 5$ & $5.87 \pm 0.25 \mathrm{a}$ & $0.32 \pm 0.03 \mathrm{a}$ & $3.56 \pm 0.36 \mathrm{a}$ \\
& $\mathrm{T} 6$ & $5.68 \pm 0.17 \mathrm{a}$ & $0.36 \pm 0.04 \mathrm{a}$ & $4.31 \pm 0.44 \mathrm{a}$ \\
& $\mathrm{T} 7$ & $5.57 \pm 0.28 \mathrm{a}$ & $0.36 \pm 0.05 \mathrm{a}$ & $4.14 \pm 0.40 \mathrm{a}$ \\
\hline
\end{tabular}

Values (mean \pm standard error) with the same letter within the same column are not significantly different by Tukey's test at $\mathrm{P} \leq 0.05$.

On the contrary, excessive $\mathrm{N}$ fertilization leads to soil acidification particularly when applied $\mathrm{N}$ exceeds crop requirement. This observation is consistent with the lower soil $\mathrm{pH}$ value in $\mathrm{T} 7 \mathrm{pH}$ 6.27) at 20 DAS compared to the initial soil $\mathrm{pH}$
(6.51). Also, excess $\mathrm{N}$ could have been converted to nitrate through microbial nitrification. In this process, hydrogen ions are released when nitrate is leached from the soil resulting in higher hydrogen concentration in the soil. 
Generally, all the treatments show similar effects on soil total $\mathrm{N}$. However, $\mathrm{T}_{3}$ was superior compared to control (T1) suggesting that effective rate of $\mathrm{N}$ applied is important because it significantly affects the amount of total $\mathrm{N}$ in soil. Moreover, variation in total $\mathrm{N}$ concentration between treatments could be attributed to $\mathrm{N}$ uptake by spinach during sampling. Although total $\mathrm{N}$ increased with $\mathrm{N}$ application, treatments ( $\mathrm{T}_{5}$ to $\mathrm{T} 7$ ) with excessive $\mathrm{N}$ (6o to $120 \mathrm{~kg} \mathrm{~N} / \mathrm{ha}$ ) showed minor decrement in total $\mathrm{N}$ at 20 DAS. Applying $\mathrm{N}$ fertilizer exceeding crop requirement $(>100 \mathrm{~kg}$ $\mathrm{N} / \mathrm{ha}$ ) leads to $\mathrm{N}$ leaching from the soil surface and plant root zone because excess $\mathrm{N}$ is not taken up by plants (Dybowski et al., 2020). Furthermore, $\mathrm{N}$ is easily leached because ammonium and nitrate are no longer held by soil particles. This observation corroborates that of Jing et al. (2018) who also found that soil total $\mathrm{N}$ decreased with increased $\mathrm{N}$ application resulting in minor changes in soil organic carbon (SOC) fractions. The minor changes in SOC was because of the limited $\mathrm{N}$ storage in soil where $\mathrm{N}$ was close to saturation (Table 2). Also, changes in SOC is affected by the type and amount of organic manure applied.

\section{Plant total N, N uptake and yield of green spinach}

Nitrogen concentration and $\mathrm{N}$ uptake in spinach at harvest are presented in Table 3. Total plant $\mathrm{N}$ content and $\mathrm{N}$ uptake varied with $\mathrm{N}$ fertilization rate. At harvest (35-DAS), total $\mathrm{N}$ concentration in $\mathrm{T} 3$ and $\mathrm{T} 4$ were significantly higher compared with control (T1) and T2. Low $\mathrm{N}$ fertilizer rate (12 to $36 \mathrm{~kg} \mathrm{~N} / \mathrm{ha}$ ) contributed to increasing total $\mathrm{N}$ concentration ( $\mathrm{T} 2$ to $\mathrm{T} 4$ ) in spinach but concentrations decreased when $\mathrm{N}$ fertilizer exceeds $60 \mathrm{~kg} \mathrm{~N} / \mathrm{ha}$ ( $\mathrm{T}_{5}$ to $\mathrm{T} 7$ ) (Fig. 1). Similarly, low levels of N input (24 to $36 \mathrm{~kg} \mathrm{~N} / \mathrm{ha}$ ) and $90 \mathrm{~kg} \mathrm{~N} /$ ha contributed to higher $\mathrm{N}$ uptake in spinach compared to other treatments including control with the exception of $\mathrm{T}_{5}$ and $\mathrm{T} 7$. These results indicated that the amount of $\mathrm{N}$ applied to the soil was not all taken up by spinach. Moreover, the amount of $\mathrm{N}$ applied exceeding $100 \mathrm{~kg} \mathrm{~N} / \mathrm{ha}$ is considered as over-application resulting in soil $\mathrm{N}$ accumulation in the form of $\mathrm{NO}_{3}-\mathrm{N}$ but which is easily lost from the soil through leaching and denitrification. This finding is in agreement with most previous studies (Machado et al., 2020; Peter et al., 2019).

Table 3. Effects of different $\mathrm{N}$ fertilizer rate on plant total $\mathrm{N}$ and $\mathrm{N}$ uptake in spinach after two cycles of cultivation.

\begin{tabular}{lll}
\hline Treatment & Plant total N (\%) & N uptake (mg N/ kg DW) \\
\hline T1 & $4.46 \pm 0.38 \mathrm{bc}$ & $85.20 \pm 19.15 \mathrm{~b}$ \\
$\mathrm{~T} 2$ & $4.16 \pm 0.40 \mathrm{c}$ & $81.34 \pm 14.82 \mathrm{~b}$ \\
$\mathrm{~T} 3$ & $5.70 \pm 0.14 \mathrm{a}$ & $176.86 \pm 19.13 \mathrm{a}$ \\
$\mathrm{T} 4$ & $5.91 \pm 0.33 \mathrm{a}$ & $172.80 \pm 15.19 \mathrm{a}$ \\
$\mathrm{T} 5$ & $5.50 \pm 0.19 \mathrm{ab}$ & $157.45 \pm 17.35 \mathrm{ab}$ \\
$\mathrm{T} 6$ & $5.33 \pm 0.21 \mathrm{abc}$ & $194.44 \pm 28.88 \mathrm{a}$ \\
$\mathrm{T} 7$ & $5.20 \pm 0.17 \mathrm{abc}$ & $153.17 \pm 22.35 \mathrm{ab}$ \\
\hline Values (mean \pm standard error) with the same letter within the same column are not significantly different by
\end{tabular}

With the exception of control (no $\mathrm{N}$ fertilization), all treatments with $\mathrm{N}$ fertilization significantly increased fresh weight (FW) of spinach compared with control (T1) (Fig. 2). However, T6 contributed to higher yield compared with control, T2 and T7. The higher FW of T6 could be attributed to the readily available $\mathrm{N}$ in soil for plant uptake. Nevertheless, applied $\mathrm{N}$ rate of 24 to $90 \mathrm{~kg} / \mathrm{N}$ ha showed no significant difference in yield ( $\mathrm{T}_{3}$ to T6). This finding suggested that comparable spinach yield could be achieved with low $\mathrm{N}$ input when crop efficiently used the supplied N. In this study, $\mathrm{N}$ input exceeding $120 \mathrm{~kg} \mathrm{~N} / \mathrm{ha} \mathrm{(T7)}$ contributed to a decrease in yield. This could be attributed to the surplus of $\mathrm{N}$ and over-fertilization effect that inhibited plant growth and yield performance. Moreover, excess $\mathrm{N}$ above the optimum level required by plants leads to nutrient imbalance and saturation of soluble salts in soil that suppressed the availability of other nutrients required by plants for their growth and development. 


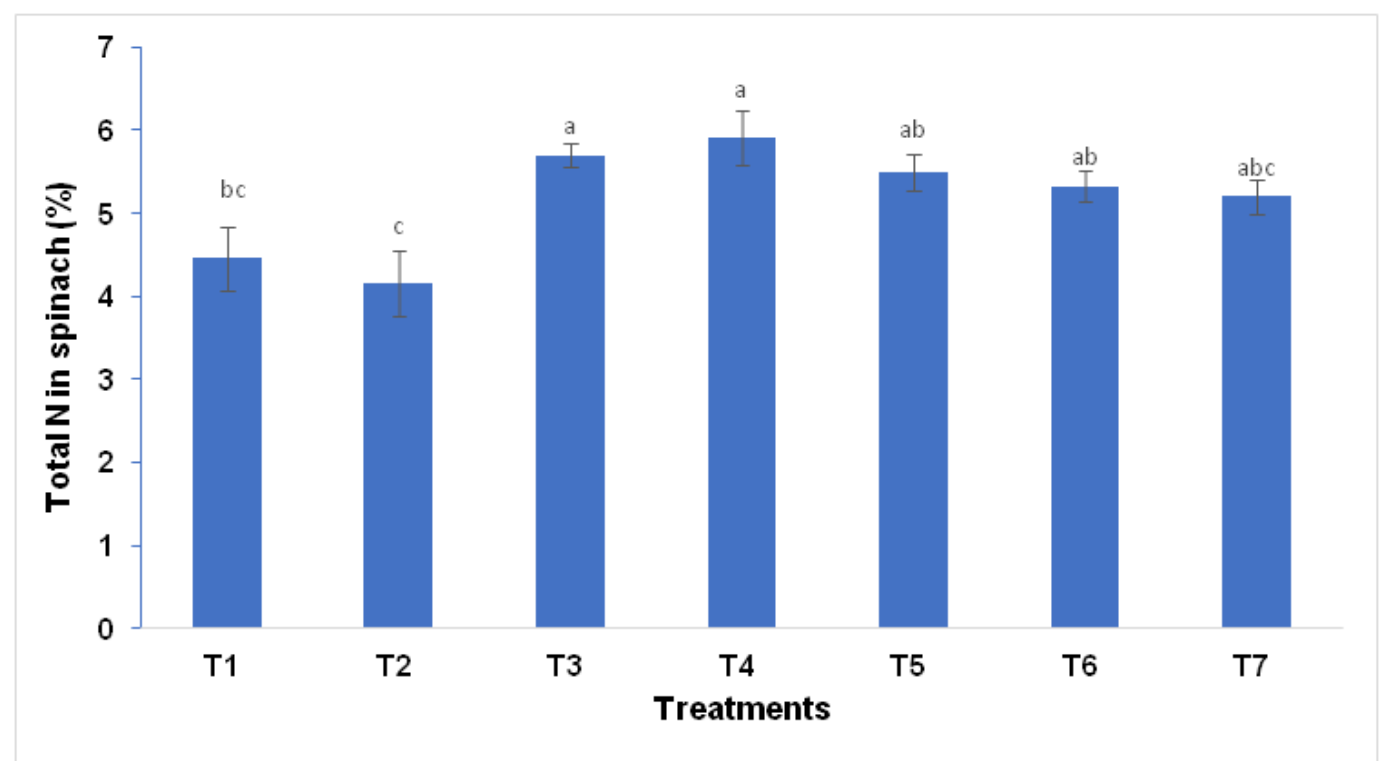

Fig. 1: Effect of different $\mathrm{N}$ rate input on mean total $\mathrm{N}$ concentration in spinach at harvest. Error bars represents standard error of the mean. Means with different letters indicate significant difference between treatments by Tukey's test at $\mathrm{P} \leq 0.05$.

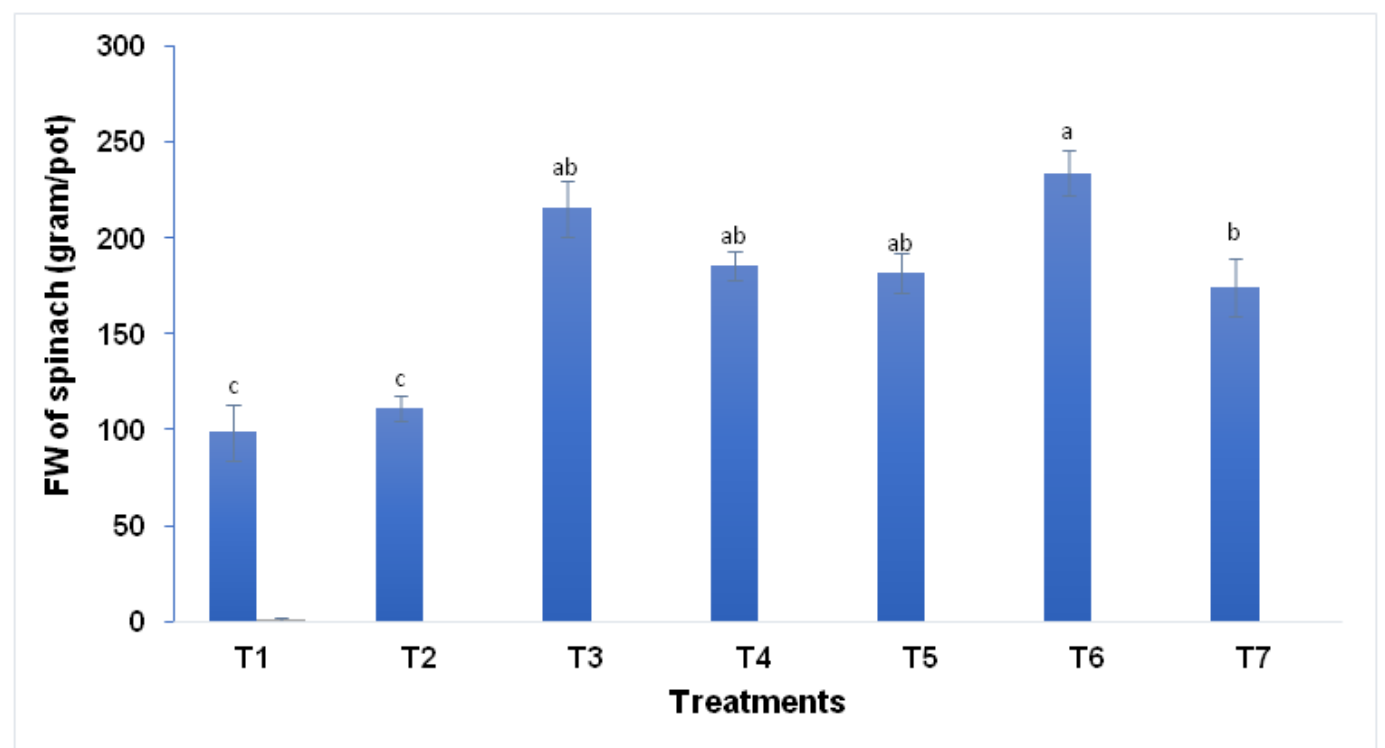

Fig. 2: Effect of different $\mathrm{N}$ rate input on mean spinach yield at harvest. Error bars represents standard error of the mean. Means with different letters indicate significant difference between treatments by Tukey's test at $\mathrm{P} \leq 0.05$.

Among the treatments, T6 with $90 \mathrm{~kg} \mathrm{~N} / \mathrm{ha}$ was most effective in improving $\mathrm{N}$ uptake and fresh yield of spinach. This could be attributed to the amount of $\mathrm{N}$ rate applied in $\mathrm{T} 6$. The $\mathrm{N}$ input at 90 $\mathrm{kg} \mathrm{N} / \mathrm{ha}$ corresponded to the optimum retention of soil $\mathrm{N}$ resulting in timely availability of $\mathrm{N}$ for uptake by spinach leading to higher yield.

\section{Conclusion}

The results from the study showed that moderate $\mathrm{N}$ fertilizer rate (24 to $90 \mathrm{~kg} \mathrm{~N} / \mathrm{ha}$ ) improved $\mathrm{N}$ uptake and yield of green spinach. Adequate supply of $\mathrm{N}$ in the soil solution must be maintained to a satisfactory level for crop growth and 
development. Thus, $\mathrm{N}$ availability not only depends on the $\mathrm{N}$ concentration of the soil solution but also on the ability of the soil to maintain $\mathrm{N}$. The findings from the study suggest that reducing $\mathrm{N}$ fertilizer rate in accordance to crop $\mathrm{N}$ requirement offers an alternative $\mathrm{N}$ nutrient management strategy that efficiently improved soil $\mathrm{N}$ availability and uptake in leafy vegetable without reducing productivity. Excessive $\mathrm{N}$ fertilization instead leads to adverse effects including yield reduction and pollution such as eutrophication. As for future research, rather than high yield production, the potential production of the improved nutritional quality in plants should be taken into consideration, as plants are the ultimate source of nutrients for human and livestock.

\section{Conflict of interest statement}

Authors declare that they have no conflict of interest.

\section{Acknowledgement}

The authors wish to thank staff of Soil Chemistry Laboratory, Malaysian Agricultural Research and Development Institute (MARDI) and Department of Land Management, Faculty of Agriculture, University Putra Malaysia (UPM) for their assistance.

\section{References}

Darren, C.P., Kosala, R., Vanessa, J.M., Noriyuki, K., Yusaku, U., Herbert, J.K., 2020. The intersection of nitrogen nutrition and water use in plants: new paths toward improved crop productivity. J. Exp. Bot. 71 (15), 44524468.

Dybowski, D., Dzierzbicka-Glowacka, L.A., Pietrzak, S., Juszkowska, D., Puszkarczuk, T., 2020. Estimation of nitrogen leaching load from agricultural fields in the Puck Commune with an interactive calculator. PeerJ. 1-21.

Ida, D.M., Eugenio, C., Lucia, O., Sabrina, N., Youssef, R., Giuseppe, C., Christophe, E., Mauro, M., 2020. Nitrogen use and uptake efficiency and crop performance of baby spinach (Spinacia oleracea L.) and lamb's lettuce (Valerianella locusta L.) grown under variable sub-optimal $\mathrm{N}$ regimes combined with plant-based biostimulant application. Agronomy. 10 (278), 1-15.

Jabatan Pertanian Malaysia, DOA., 2018. Booklet statistik tanaman (Sub-sektor tanaman makanan).

Jing, L., Xueping, W., Mesfin, T.G., Huijun. W., Dianxiong, C., Bisheng, W., Baoguo, L., Jiancheng, Z., Yongshan, L., Jilong, X., 2018. Response of soil organic carbon fractions, microbial community composition and carbon mineralization to high-input fertilizer practices under an intensive agricultural system. PLoS One. 13 (4), 1 - 16.

Junyong, M., Fengfeng, K., Xiaoqin, C., Hairong, H., 2018. Response of soil organic carbon and nitrogen to nitrogen deposition in a Larix principis-rupprechtii plantation. Scient. Rep. 8 (8638), 1-10.

Khan, M.N., Mobin, M., Abbas, Z. K., 2018. Fertilizer and their contaminants in soils, surface and groundwater. In: Dominick, A., DellaSala, Michael, I.G., (eds.) The Encyclopedia of the Anthropocene, Oxford: Elsevier. 5, 225-240.

Laila, E., Mariame, H., Chaimae, R., Lahsen, E., Hassane, G., 2019. Impact of excessive nitrogen fertilization on the biochemical quality, phenolic compounds and antioxidant power of Sesamum indicum L. seeds. J. Food Qual. Vol. 2019, Article ID 9428092, pp. $1-6$.

Machado, R.M.A., Alves-Pereira, I., Lourenco, D., Ferreira, R.M.A., 2020. Effect of organic compost and inorganic nitrogen fertigation on spinach growth, phytochemical accumulation and antioxidant activity. Heliyon. 6, 1-8.

Machado, R.M.A., Alves-Pereira, I., Ferreira, R.M.A., 2018. Plant growth, phytochemical accumulation and antioxidant activity of substrate-grown spinach. Heliyon. 4, 1-21.

Mohamed, A.M.E, Ali, A.A., Haythum, M.S., Samira, E.M., Mahmoud, F.S., Abdullah, A.A., Talaat, H.I.S., Abdullah, A.I., 2020. Interaction effects of nitrogen source and irrigation regime on tuber quality, yield, and water use efficiency of Solanum tuberosum L. Plants. 9 (110), 1-20.

Muhammad, Q., Waqas, A., Huang, J., Fan, H., Shi, X., Jiang, X., Liu, K., Xu, Y., He, Z., Waleed, A., Asad, S., Huimin, Z., 2019. Soil carbon $(\mathrm{C})$, nitrogen $(\mathrm{N})$, and phosphorus 
(P) stoichiometry drives phosphorus lability in paddy soil under long-term fertilization: A fractionation and path analysis study. PLoS One. 14 (6), 1-20.

Peter, O., Lawrence, A., William R.R., 2019. Nitrogen uptake efficiency and total soil nitrogen accumulation in long term beef manure and inorganic fertilizer application. Int. J. Agron. vol. 2019, Article ID 9594369, pp. 1-6.

Singh, B., 2018. Are Nitrogen Fertilizers Deleterious to Soil Health? Agronomy. 8 (48), 1-19.

\section{How to cite this article:}

Faridah, M., Roslan, I., Arina, A. S., 2020. Effect of reduced nitrogen fertilizer rate on nitrogen uptake and yield of spinach (Amaranthus spp.). Int. J. Curr. Res. Biosci. Plant Biol. 7(10), 1-7.

doi: https://doi.org/10.20546/ijcrbp.2020.710.001 